\title{
Using Newspapers as Learning Media to Teach Reading Skills
}

\author{
Brigitta Septarini Rahmasari, SS., M.Pd
}

\begin{abstract}
For teachers the newspaper offers a special attraction. It has been called the living textbook and it lives up to that name. The newspaper can be used to enhance skills in reading. Critical thinking is the natural outgrowth of using a newspaper to learn. Unlike textbooks, which are several years outdated by the time they get into students' hands, the newspaper comes alive with information. The newspaper expands the curriculum with an unlimited amount of information to use as background for learning activities. These activities will help students improve their reading skills. These skills are how to find the main idea, how to increase vocabulary, how to find detail, how to make inference and how to find reference. They will employ many critical thinking skills as they are required to interact with the authentic material found in the newspaper.
\end{abstract}

Keywords: newspaper, improve, reading skill

\section{A. Introduction}

Ask any teacher what comes to mind as an authentic reading activity for their learners and almost certainly one of the first things they will say is "using a newspaper". Why do so many teachers like using newspapers? Well, to start with, newspapers are much more current than coursebooks. There is also a lot of information in newspapers which makes them an excellent springboard for lessons. Finally, there are lots of different kinds of texts in newspapers (narratives, stories, letters, advertisements, report)

So what do teachers do with newspapers? One of the problems with newspapers is that they are often used as an up-to-date coursebook activity. The teacher applies the same pedagogical principles and exercises that are in the coursebook. Two major problems tend to emerge are first, It can be extremely timeconsuming for teachers Second, it is not necessarily interesting for learners

When using a newspaper, the task itself should be authentic wherever possible, not merely the material. One aim of reading newspapers should be to encourage their reading outside the classroom as well. If not, you run the risk of killing the enjoyment from it. Get learners to read outside class as much as possible. Make your tasks as authentic as the material. Tasks like "underline all the verbs in the past" are of limited value and should be used sparingly. Think about what people do when they read newspapers in their own language.

There are many studies that show the positive effects of using newspaper-based instruction. With a good teacher and application of sound teaching practices, 
students can benefit immensely from newspaper-based instruction. Students develop a keen awareness of the world and their communities, and gain a positive effect on attitudes toward school, community and subject matter. Students who use newspapers as a principal source material have better achievement scores in reading than their matched counterparts, who rely only on textbooks. In one study, reading skills increased two grade levels for students who used newspapers compared to those using traditional methods.

A newspaper can provide one of the most comprehensive resources to help a student become a reader. Once a student learns letter names and sounds, then sight words, he or she becomes more fluent and can move more quickly through text, accomplishing more difficult reading tasks such as learning new vocabulary and understanding what is read. By learning systematically, the students learn how to learn.

\section{B. Reading Comprehension}

Alderson defines reading as “...an enjoyable, intense, private activity, from which much pleasure can be derived, and in which one can become totally absorbed (2000:28)." Reading means different things to different people, for some it is recognizing written words, while for others it is an opportunity to teach pronunciation and practice speaking. However reading always has a purpose. It is something that we do everyday, it is an integral part of our daily lives, taken very much for granted and generally assumed to be something that everyone can do.

The reason for reading depends very much on the purpose for reading. Reading can have three main purposes, for survival, for learning or for pleasure. Reading for survival is considered to be in response to our environment, to find out information and can include street signs, advertising, and timetables. It depends very much on the day-to-day needs of the reader and often involves an immediate response to a situation. In contrast reading for learning is considered to be the type of reading done in the classroom and is goal orientated. While reading for pleasure is something that does not have to be done. For Nuttall (1996) the central ideas behind reading are:

- the idea of meaning;

- the transfer of meaning from one mind to another;

- the transfer of a message from writer to reader;

- how we get meaning by reading;

- how the reader, the writer and the text all contribute to the process.

Readers process texts in two ways, either Top-Down or Bottom-Up. Bottom- 
up processing is when the reader builds up meaning by reading word for word, letter for letter, carefully scrutinizing both vocabulary and syntax. This is often associated with poor or slow readers, but can sometimes occur when the readers own schema knowledge is inadequate. Top-Down processing is the opposite, where a global meaning of the text is obtained, through "clues" in the text and the reader's good schema knowledge. This is often associated with a good reader, who does not read word for word but quickly and efficiently. The most comprehensive description of the reading process are interactive models, "...in which every component in the reading process can interact with any other component... (Alderson 2000:18)", combining elements of both bottom-up and top down models. Reading is considered to be an interactive process (a conversation between writer/reader, even though the writer is not present) and for it to occur both processes are necessary, top-down to predict the meaning and bottom-up to check it. The two are therefore complementary ways of processing a text. Our knowledge and experiences of the world around us also influence how a text is read or processed, this is known as schema theory (Bartlett 1932). It operates actively and constructively, with our knowledge of the world being a continuous process that upon receiving new information interprets it on the basis of what is already known. Good readers have an idea of what is normal (linguistically and conceptually) and of how the world works, therefore when reading they make use of existing schemata and then modify them with any new information. They also have expectations or make predictions before reading that are either reinforced, challenged or modified after reading. Schemata has also been described as “...cognitive constructs which allow for the organization of information in the long term memory..." (Widdowson 1983:34). Often a writer will presume that the target reader has the relevant schemata to read the text and will therefore leave certain facts out or unstated (presuppositions) but this creates problems when the writer and reader do not share the same relevant schema.

\section{Definition of authentic materials}

The notion of authenticity has been much discussed. Marrow's definition will serve us well. He relates it to "a stretch of real language, produced by a real speaker or writer for a real audience and designed to carry a real message of some sort.”(1977:13) Harmer (1983:146) says that authentic texts (either written or spoken) are those which are designed for native speakers: They are real text 
designed not for language students, but for the speakers of the language in question. Nunan (1989:54) thinks that a rule of thumb for authenticity here is any material which has not been specifically produced for the purposes of language teaching.

Authentic material has traditionally been defined as that written for native speakers, that is, ordinary everyday material not provided specifically for the language teaching purpose.

Authentic materials must be used in accordance with students' ability. (Baird, 2004) . The text should be used to serve its original purpose as if it is used outside the classroom. For example, if students are working with health brochures, they must look for information they need, rather than a list of new words chosen by the teacher (Jacobson, Degener, \& Purcell-Gates, 2003). In this respect, Taylor (1994) states that "authenticity is not a characteristic of a text in itself: it is a feature of a text in a particular context. Therefore, a text can only be truly authentic in the context for which it was originally written."

Authentic texts have been defined as "...real-life texts, not written for pedagogic purposes" (Wallace 1992:145) They are therefore written for native speakers and contain "real"language. They are "...materials that have been produced to fulfil some social purpose in the language community." (Peacock (1997),

Based on these definitions, we can find the real meaning of authentic materials: they are real language; produced for the native speakers; designed without the teaching purposes. In this sense, there are a large amount of authentic materials in our life such as newspaper and magazine articles, TV and radio broadcast, daily conversations, meetings, documents, speech, and films. One of the most useful is the Internet. Whereas newspapers and other materials date very quickly, the Internet is continuously updated, more visually stimulating as well as interactive.

Authentic materials can be classified into three categories.

1. Authentic Listening-Viewing Materials: TV commercials, quiz shows, cartoons, news clips, comedy shows, movies, soap operas, professionally audio-taped short stories and novels, radio ads, songs, documentaries, and sales pitches.

2. Authentic Visual Materials: slides, photographs, paintings, children' artwork, stick-figure drawings, wordless street signs, silhouettes, pictures from magazine, ink blots, postcard pictures, wordless picture books, stamps, and X-rays.

3. Authentic Printed Materials: newspaper articles, movie 
advertisements, astrology columns, sports reports, obituary columns, advice columns, lyrics to songs, restaurant menus, street signs, cereal boxes, candy wrappers, tourist information brochures, university catalogs, telephone books, maps, TV guides, comic books, greeting cards, grocery coupons, pins with messages, and bus schedules

In this paper, the writer uses newpaper in teaching reading comprehension

\section{How to use newspaper to teach reading}

Newspapers can be utilized to teach reading to students of all different ages and skill levels. There are a number of techniques that you can utilize with this useful tool.

\section{Letter recognition}

Even the youngest of children can start the learning-to-read process with newspapers. Newspapers can help provide letter recognition. Children need to get accustomed to seeing letters in different sizes, fonts and prints. Between the articles and the print ads, a newspaper can provide this variation. The teacher can give children newspapers or use a projector to make it big and ask that students recognize the letters that they see.

Students can also be asked to pick out certain letters in a newspaper. They may be assigned to find an article themselves (or be given one) and to use a highlighter or crayon to mark instances of certain letters. With a lot of print, they should find many instances of all of the different letters.

\section{Reading words}

Of course newspapers can be utilized when teaching students to read and recognize words. You will need to find a newspaper that matches the skill level of the student, thus in this case, it may be more for an older child learning larger words. Students can be asked to read portions of the newspaper out loud. Words that are difficult or new can be explained by the teacher as they are being read. If the teacher is using a particular article to teach, then he or she can make a guide to accompany it that includes some of the words as vocabulary words, has their definition and provides hints for pronunciation.

\section{Reading comprehension}

It is important that students not only read the words in a written 
piece, but be able to correctly understand what they are reading. Newspapers can help with this reading comprehension. A teacher can assign a particular newspaper article for students to read or they can allow the student to pick out an article for themselves. The teacher can then ask questions that help the student learn how to read in a way to pick up the knowledge. Questions they may ask include "What is the subject of the article?" and "Does the article pose any additional questions?"

\section{Identify the strategy.}

If you are a reading teacher, reinforce one strategy at a time. For example, if you have introduced the skill of summarizing, have students read short articles and work in pairs or small groups. Each student can read a paragraph and highlight the important details. Then they can paraphrase these details into sentences that best retell the event related in the article.

\section{What's in the news today?}

Materials: English language newspapers

Distribute the newspapers, one for each group of two or three learners. Tell them they have a time limit with which to skim through the newspaper. When the timit limit is up, ask two groups to get together and report to each other everything they remember that is in the news. They must do this in English, and cannot refer to the newspapers (this is important, because otherwise you may get one or two learners who bury their heads in the paper and don't participate!). Do feedback as a whole group. This is a combined reading and speaking activity, although the time limit forces learners to use the reading skill of skimming.

\section{Newspaper show and tell}

Materials: English language newspapers, enough so that each learner has one (or a section of one)

Give each learner a newspaper and tell them that for homework, you would like them to take the newspaper home, choose an article and prepare a report on it to classmates. The report must be no longer than five minutes, and should include peer teaching on new vocabulary that the learner encounters in their article. This encourages reading outside the classroom, as well as dictionary use. Set up a schedule and have the 
last five minutes of every class devoted to news reports by a learner or learners and make this project part of your class routine.

\section{Do it yourselves newspaper quiz}

Materials: One newspaper, or section of a newspaper for each group

Give each group of four or five learners a newspaper and a piece of paper. Tell them that they have ten minutes to make a quiz based on that section of the newspaper. Suggest different kinds of questions, e.g. How long has $\mathrm{X}$ been... Where is ...? How many people...? What happened in ...? Who is...? Who won...? How much did...pay/cost...?

In groups, learners write six questions. Circulate and monitor, checking the grammar and spelling in the questions (and making sure that questions are not too difficult!) When the groups are finished, they pass the paper and the questions to another group. Set a time limit for new groups to do the quiz. Repeat the process if you have time. Do feedback and check the answers to the quizzes. This is good to practise the reading skill of scanning for information.

Why do all the work making a class for a news story when it is right there for you? You can download a free lesson based on a news story every month at onestopenglish.com. There are different lessons for elementary, intermediate and advanced learners for each news story. Take a look at the archive for some great preprepared materials.

\section{E. Conclusion}

Using newspapers can be used by teachers in teaching reading. Using newspaper is one of learning media to encourage the students to read in English outside the classroom. At the same time, they are provided with experience in reading a variety of authentic texts of current and general interest to supplement the teaching materials, which are specifically written for pedagogic purposes. For their part, the students become familiar with a variety of genres, like advertisements, reviews, reports, statistics, captions and notices, to name but a few. Reading newspapers also provides an avenue through which the students can expand their knowledge schema and develop their reading skills. Besides this, it can be a large extent motivate the students to read a readily available and relatively cheap 
source of discourse in English., which contains texts that offer high interest content.

\section{F. References}

Alderson, J.C. (2000) Assessing Reading Cambridge, C.U.P.

Allwright, R. (1977) Language Learning through communication practice ELT Document 76,3:2-14 The British Council reprinted in Brumfit, C.J. \& Johnson, K. (1979) The Communicative Approach to Language Teaching Oxford, O.U.P. pp 172-173

Anderson, N.J. (1999) Exploring Second Language Reading - Issues and Strategies Canada, Heinle \& Heinle

Bartlett, F.C. (1932) Remembering Cambridge, C.U.P.

Breen, M.P. (1985) Authenticity in the language classroom Applied Linguistics 6/1 pp60-70

Brumfit, C.J. \& Johnson, K. (1979) The Communicative Approach to Language Teaching Oxford, O.U.P.

Carrell, P.L., Devine, J. \& Eskey, D.E. (Editors) (1988) Interactive Approaches to Second Language Reading Cambridge, C.U.P.

Davies, A. (1984) Simple, simplified and simplification: what is authentic? in Alderson, J.C. \& Urquhart, A.H. (1984) Reading in a Foreign Language London, Longman pp181198

Martinez, A.G. (2002) Authentic Materials: An Overview on Karen's Linguistic Issues http://www3.telus.net/linguisticsissues lauthenticmaterials.html

Nuttall, C. (1996) Teaching Reading Skills in a foreign language (New Edition) Oxford,Heinemann

Peacock, M. (1997) The Effect of Authentic Materials on the Motivation of EFL Learners in English Language Teaching Journal 51, pp 2
Richard, J.C. (2001) Curriculum Development in Language Teaching Cambridge C.U.P

Senior, R (2005) Authentic Responses to Authentic Materials in English Teaching Professional38, pp71

Wallace, C. (1992) Reading Oxford, O.U.P. 
